possibilities of pushing into the frontiers of disciplinary research. At the same time, there were few contributions from any discipline which were solely comprehensible to others in that discipline; the Association, as well as African programmes in American universities, and faculty seminars on Africa, may be credited for helping to avoid a too narrowly oriented approach to African studies.

At least 5 disciplines were represented among the contributors. Anthropologists and political scientists continued their leading position, accounting for over two-fifths of the 70-odd papers presented. Geographers and historians accounted for another fifth of the papers. Welcome because of their usual meagre attendance were several natural scientists and a few specialists in African literature. Disciplines which should be better represented include sociology and economics. There appears to be a dearth of American sociologists in all area studies, while the basic importance of economic development suggests that a much greater participation by economists with concern in African affairs is needed.

Welcome additions to the usual disciplinary panels-which outnumbered the regional panels by three to one-were those on pre-history and science and technology. The Africanists discovered Malagasy and the Mascarenes for the first time, while two panels on North Africa indicated that they were not content to disgorge this part of the continent to the Arabists and Middle East specialists. Many papers were not devoted to any particular area; the others demonstrated an overwhelming concentration on Commonwealth areas, there being a deplorable dearth of papers on French- and Portuguesespeaking territories.

Professor Paul J. Bohannan was elected president to succeed Professor James S. Coleman; Professor J. H. Greenberg, the incoming vice-president, will succeed to the presidency in $1965-6$. Professor L. Gray Cowan continues as executive secretary.

WILLIAM A. HANCE

Graduate Program in Geography, Columbia University, New York

\title{
Seminar on Narcotics Problems in Developing Countries in Africa
}

Addis Ababa, Ethiopia, I I-22 November 1963

While most African countries have no real cause for alarm concerning narcotic drug addiction and illicit trafficking, the possibilities for the future in such a huge and rapidly changing area call for the utmost vigilance. Only in this way can the tragedy of large-scale addiction which has afflicted other wide regions of the world be avoided. Urbanisation, internal migration, and detribalisation are factors which might well sow the seeds of future trouble. The United Nations therefore organised this regional seminar, the first of its kind in Africa, as part of its programme of technical assistance in narcotics control.

The seminar was attended by representatives from i 7 African countries, drawn mostly from among senior officers in the fields of narcotics control, public health, customs, and law enforcement services. His Excellency Ato 
Abebe Retta, Minister of Public Health in the Government of Ethiopia, opened the conference at Africa Hall. Among the experts attending were: Dr Thomas A. Lambo, Professor of Psychiatry, University of Ibadan, Nigeria; Mr Patrick P. O'Carroll, Director of the United States Federal Government School of Law Enforcement, Washington, D.C.; Mr L. O. Edet, Deputy Inspector General of Police of Nigeria ; and several highly experienced officials from U.N. agencies, including the Permanent Central Opium Board and the World Health Organisation.

The topics discussed at the seminar included: drug addiction, with special reference to the medical and social aspects, the treatment and rehabilitation of addicts, and the local production of drugs in Africa; international treaties on narcotic drugs (there are nine treaties in force, to which more than roo states are parties), and the present system of international control; illicit drug traffic, including the role of Interpol, and the possibility of United Nations technical assistance, in controlling it.

Eight background papers were prepared by the U.N. Division of Narcotic Drugs; M Heiby, Chief of the Identification Service and of the Police Laboratory, Malagasy, gave the results of an 'Enquiry on Somorona' ( a drug which, when taken mixed with cannabis, is said to produce a fighting spirit); and Dr T. Asuni of Nigeria read a paper on 'Medical and Social Problems of Drug Addiction in West Africa'. The Division of Narcotic Drugs also made available a small library of books, documents, and pamphlets, and showed some relevant films.

The following are some of the recommendations and suggestions made by the seminar, which will form the basis for future action:

r. Developing African countries should have stringent laws on the cultivation, production, and possession of cannabis (Indian hemp), which is widely misused in Africa, to facilitate law enforcement.

2. The attention of African governments should be drawn to the troubles which might arise from the uncontrolled distribution and sale of pharmaceutical products. A close watch should be kept on the import and distribution of amphetamines (stimulants), barbiturates (sleeping pills), and tranquillisers.

3. A study should be made of hallucinogenic substances and their uses among African tribes.

4. African governments should review their control of narcotic drugs to ensure there are no leakages from legal supplies.

5. Governments of developing countries should urgently consider the setting up of national centres for research into the socio-medical aspects of addiction, and the properties and uses of different drugs, including those from indigenous plants, which affect the human nervous system. An African regional centre should be established, in co-operation with the United Nations and the World Health Organisation, for such studies.

6. Better information is needed on the illicit drug traffic in Africa at national, regional, and international levels. This could be done in co-operation with the United Nations and Interpol.

7. Governments of African countries should ensure heavy legal penalties 
for drug traffickers. Those responsible for enforcement should be specially trained in identifying drugs, detecting offences, and prosecution procedures.

8. African governments should keep in close and continuous contact with one another-particularly with neighbouring countries where there may be a common illicit traffic problem-and with the international organisations concerned.

The range of topics covered and the recommendations made during such a short period show that this seminar was something of a tour de force. The discussions were well attended, very lively and fruitful, and excellent facilities were provided by the administrative services of the E.C.A. in Addis Ababa. The Division of Narcotic Drugs will give serious attention to the recommendations, and will urge their consideration by the United Nations and the specialised agencies concerned.

DANIEL A. CHAPMAN

Division of Narcotic Drugs, European Office of the United Nations, Geneva

\section{University of East Africa Conferences on Public Policy: I. East African Federation \\ Nairobi, Kenya, 26-30 November 1963}

This was the second in a series of three conferences on public policy, organised by the University of East Africa and financed by the Ford Foundation, whose aim is to bring together policy-makers and academics for discussions on major public issues.

In attendance were delegations, of at least a dozen each, from Uganda, Kenya, and Tanganyika, consisting mainly of Cabinet Ministers, parliamentary secretaries, other M.P.s, and civil servants, as well as representatives of public corporations, political parties, and trade unions. Small delegations from Ethiopia, Northern Rhodesia, Nyasaland, Southern Rhodesia, and Zanzibar were also invited. A group of ro 'visiting specialists' from overseas with experience of federal systems and problems elsewhere were invited to take part. Among these were six economists: Ursula Hicks and Arthur Hazlewood from Oxford, Pitamber Pant of the Indian Planning Commission, Vladimir Kollontai from Moscow, Jan Auerhan from Prague, and Benton Massell (who was unable to attend but contributed a paper) from the United States. The others were a lawyer, S. A. de Smith from the London School of Economics, and three political scientists, Arthur MacMahon of Columbia University, A. H. Birch from Hull University, and myself. A group of a dozen 'local specialists' drawn mainly from E.A.C.S.O. and from the economists, lawyers, and political scientists at the University Colleges in East Africa also presented papers and played a significant role in the discussions. The total number of participants, including 22 observers, amounted to over 90.

Because of the heavy commitments of the political leaders-the Kenya legislature was in session at the time making preparations for independence a fortnight later, and the E.A.C.S.O. Central Legislative Assembly was also meeting at the same time in Kampala-not all who were invited were able 